\title{
Methanospirillum lacunae sp. nov., a methane- producing archaeon isolated from a puddly soil, and emended descriptions of the genus Methanospirillum and Methanospirillum hungatei
}

Correspondence

Takao lino

iino@jcm.riken.jp
Takao lino, ${ }^{1,2}$ Koji Mori $^{2}$ and Ken-ichiro Suzuki ${ }^{2}$

\author{
${ }^{1}$ Japan Collection of Microorganisms, RIKEN BioResource Center, 2-1 Hirosawa, Wako, Saitama \\ 351-0198, Japan \\ ${ }^{2}$ NITE Biological Resource Center (NBRC), National Institute of Technology and Evaluation (NITE), \\ 2-5-8, Kazusakamatari, Kisarazu, Chiba 292-0818, Japan
}

A mesophilic, hydrogenotrophic methanogen, designated strain $\mathrm{Ki8}-1^{\top}$, was isolated from soil. Cells were strictly anaerobic, Gram-stain-negative, non-sporulating, motile by means of a single flagellum or tufted flagella, and curved or wavy rod-shaped (11-25 $\mu \mathrm{m}$ long). The temperature and $\mathrm{pH}$ for optimum growth were $30{ }^{\circ} \mathrm{C}$ and 7.5. The strain grew best in basal medium without the addition of $\mathrm{NaCl}$. Methane was produced from $\mathrm{H}_{2}$ and formate. Acetate or yeast extract was required for growth. The $\mathrm{G}+\mathrm{C}$ content of the genomic DNA of strain Ki8-1 ${ }^{\top}$ was $45.3 \mathrm{~mol} \%$. Phylogenetic analysis based on $16 \mathrm{~S}$ rRNA gene sequences revealed that strain $\mathrm{Ki}-1^{\top}$ was a member of the genus Methanospirillum and showed $95.1 \%$ sequence similarity to Methanospirillum hungatei NBRC $100397^{\top}$. On the basis of its phenotypic characteristics and phylogenetic position, strain $\mathrm{Ki8}-1^{\top}$ is considered to represent a novel species of the genus Methanospirillum, for which the name Methanospirillum lacunae sp. nov. is proposed. The type strain is Ki8-1 ${ }^{\top}\left(\operatorname{NBRC} 104920^{\top}=J C M 16384^{\top}=\right.$ DSM $\left.22751^{\top}\right)$. Emended descriptions of the genus Methanospirillum and of Methanospirillum hungatei are also provided.
The production of methane has been regarded as a good source of renewable energy from biomass and its waste. Therefore, methane-producing archaea (methanogens), which are responsible for the final step of the anaerobic degradation of organic substances, have been investigated by both culture-dependent and culture-independent approaches (Bräuer et al., 2006; Joye et al., 2009; Narihiro et al., 2009; Zengler et al., 1999).

The methanogens are phylogenetically accommodated in the phylum Euryarchaeota (Garrity \& Holt, 2001), and, at the time of writing, approximately 120 named species in 32 genera have been recognized according to the List of Prokaryotic names with Standing in Nomenclature (http:// www.bacterio.cict.fr/). These methanogens have frequently been isolated from anoxic environments such as paddy fields, peatlands, wetlands, the intestinal tract of animals, anaerobic digestors, freshwater or marine sediments and hot springs (Jones et al., 1987; Liu \& Whitman, 2008).

Recently, we have successfully isolated a novel methanogen, designated strain Ki8- $1^{\mathrm{T}}$, from anoxic soil. In this paper, we

The GenBank/EMBL/DDBJ accession numbers for the $16 \mathrm{~S}$ rRNA and $m c r A$ gene sequences of strain $\mathrm{Ki8}-1^{\top}$ are AB517986 and AB517988, respectively. describe the isolation and characterization of this strain and show that it represents a novel species of the genus Methanospirillum. In addition, we also provide emended descriptions of the genus Methanospirillum and of Methanospirillum hungatei according to our study and the report of Patel et al. (1976).

Soil was collected from a puddle at Kisarazu, Chiba, Japan. Spring water accumulates at this site year round, and therefore anaerobic conditions are maintained in the soil. The soil sample was kept in a sealed nylon bag with an $\mathrm{O}_{2}$-absorbing and $\mathrm{CO}_{2}$-generating agent (Anaero-Pack; Mitsubishi Gas Chemical) until inoculation to fresh medium.

For enrichment, $1 \mathrm{~g}$ of soil was used for inoculation into $20 \mathrm{ml}$ of basal medium in a vial sealed with a tight-fitting butyl rubber stopper. The basal medium comprised (per litre): $0.54 \mathrm{~g} \mathrm{NH}_{4} \mathrm{Cl}, 0.14 \mathrm{~g} \mathrm{KH}_{2} \mathrm{PO}_{4}, 0.20 \mathrm{~g} \mathrm{MgCl}_{2} \cdot 6 \mathrm{H}_{2} \mathrm{O}$, $0.15 \mathrm{~g} \mathrm{CaCl}_{2} .2 \mathrm{H}_{2} \mathrm{O}, 2.5 \mathrm{~g} \mathrm{NaHCO} 3$ and $1.0 \mathrm{ml}$ trace elements solution (Touzel \& Albagnac, 1983) containing $3.0 \mathrm{mg} \mathrm{Na} \mathrm{WO}_{4} \cdot \mathrm{H}_{2} \mathrm{O}$ but lacking $\mathrm{NaCl}$. Prior to inoculation, the $\mathrm{pH}$ of the medium was adjusted to 6.8 , dissolved air was removed by flushing with $\mathrm{H}_{2} / \mathrm{CO}_{2}(4: 1$, v/v; approximately $150 \mathrm{kPa}$ ), and $10 \mathrm{ml}$ vitamin solution $\mathrm{l}^{-1}$ (Wolin et al., 1963) and $10 \mathrm{ml}$ of a sterile stock solution of 
$\mathrm{Na}_{2} \mathrm{~S}\left(50.0 \mathrm{~g} \mathrm{l}^{-1}\right)$ were added. The enrichment culture was cultivated at $25{ }^{\circ} \mathrm{C}$ for 3 weeks and transferred several times to fresh HAB medium, which added $0.82 \mathrm{~g}$ sodium acetate $1^{-1}$ and $1 \mathrm{mg}$ ampicillin $\mathrm{l}^{-1}$ to the above basal medium. After microbial growth was observed in the medium, the culture was spread on slants of HAB medium solidified with $1.5 \%(\mathrm{w} / \mathrm{v})$ agar, and microbial colonies appearing within a few months were picked and transferred to fresh medium. The purification procedure was repeated several times to establish an axenic culture with one strain, which was designated Ki8- ${ }^{\mathrm{T}}$. After purification, the isolate was maintained in HAB medium without antibiotic. $M$. hungatei NBRC $100397^{\mathrm{T}}$, used as a reference, was also cultivated in $\mathrm{HAB}$ medium.

Cells of strain Ki8- $1^{\mathrm{T}}$ were curved or wavy rods with blunt ends, and were generally $0.5-0.6 \mu \mathrm{m}$ wide and 10.9 $25.1 \mu \mathrm{m}$ long (Fig. 1a). Some cells were $8.2 \times 0.5-$ $26.4 \times 0.7 \mu \mathrm{m}$ in size. Weak motility was observed under phase-contrast microscopy. A single polar flagellum or tufted flagella were observed by electron microscopy (Fig. $1 b, c)$. Cells of strain Ki8- $1^{\mathrm{T}}$ autofluoresced under epifluorescence microscopy, indicating the presence of the methanogen-specific coenzyme $\mathrm{F}_{420}$. Cells stained Gram-negative by conventional Gram staining.

Strain Ki8- $1^{\mathrm{T}}$ was strictly anaerobic, i.e. was able to grow in $\mathrm{HAB}$ medium under an $\mathrm{H}_{2} / \mathrm{CO}_{2}(4: 1, \mathrm{v} / \mathrm{v})$ atmosphere, but could not grow under microaerobic or aerobic conditions. Strain Ki8-1 ${ }^{\mathrm{T}}$ required acetate or yeast extract for growth. Catalase and oxidase reactions were negative. Strain Ki8- $1^{\mathrm{T}}$ grew at $15-37{ }^{\circ} \mathrm{C}$, with optimum growth at $30{ }^{\circ} \mathrm{C}$. No growth was observed at 10 or $40{ }^{\circ} \mathrm{C}$. The $\mathrm{pH}$ range for growth was 6.0-9.5, with optimum growth at $\mathrm{pH}$ 7.5. No growth was observed at $\mathrm{pH} 5.5$ or 10.0. Growth of M. hungatei NBRC $100397^{\mathrm{T}}$ was also investigated in the present study for comparison. M. hungatei NBRC $100397^{\mathrm{T}}$ grew at $20-50{ }^{\circ} \mathrm{C}$, with optimum growth at $37-45{ }^{\circ} \mathrm{C}$. No

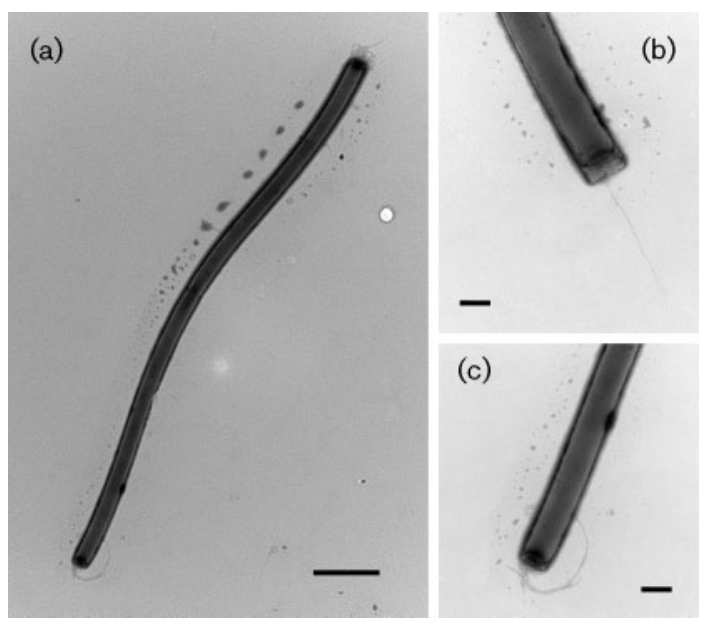

Fig. 1. Transmission electron micrographs of cells of strain $\mathrm{Ki8}-1^{\top}$. Bars: (a) $2 \mu \mathrm{m}$; (b, c) $0.5 \mu \mathrm{m}$. growth was observed at 15 or $55{ }^{\circ} \mathrm{C}$. The $\mathrm{pH}$ range for growth was 6.5-10.0, with optimum growth at $\mathrm{pH}$ 7.0-9.0. No growth was observed at $\mathrm{pH} 6.0$ or 10.5. Growth of strain Ki8- $1^{\mathrm{T}}$ and M. hungatei NBRC $100397^{\mathrm{T}}$ was observed below $1 \%(\mathrm{w} / \mathrm{v}) \mathrm{NaCl}$, and optimum growth for the two strains was observed in basal medium without the addition of $\mathrm{NaCl}$. No growth was observed at $2 \%(\mathrm{w} / \mathrm{v}) \mathrm{NaCl}$. Strain Ki8- $1^{\mathrm{T}}$ and $M$. hungatei NBRC $100397^{\mathrm{T}}$ used $\mathrm{H}_{2} / \mathrm{CO}_{2}(4: 1$, $\mathrm{v} / \mathrm{v})$ and formate $(10 \mathrm{mM})$ for growth and methane production. No growth occurred on acetate, pyruvate, methanol, ethanol, 1-propanol, 2-propanol, 1-butanol, 2butanol or trimethylamine (all at $10 \mathrm{mM}$ ). Strain Ki8- $1^{\mathrm{T}}$ and M. hungatei NBRC $100397^{\mathrm{T}}$ were susceptible to chloramphenicol and tetracycline (both at $100 \mu \mathrm{g} \mathrm{ml}^{-1}$ ), but were resistant to ampicillin, erythromycin, gentamicin, kanamycin, rifampicin, streptomycin and vancomycin (all at $100 \mu \mathrm{g} \mathrm{ml}^{-1}$ ). Strain Ki8-1 ${ }^{\mathrm{T}}$ was weakly susceptible to bacitracin $\left(100 \mu \mathrm{g} \mathrm{ml}^{-1}\right)$, whereas $M$. hungatei NBRC $100397^{\mathrm{T}}$ was resistant to bacitracin. The generation time of strain Ki8-1 ${ }^{\mathrm{T}}$ in $\mathrm{HAB}$ medium at $30{ }^{\circ} \mathrm{C}$ and $\mathrm{pH} 7.5$ was $32.3 \mathrm{~h}$, based on an increase in turbidity, and that of $M$. hungatei NBRC $100397^{\mathrm{T}}$ was $20.7 \mathrm{~h}$ at $40{ }^{\circ} \mathrm{C}$ and $\mathrm{pH}$ 7.5. The genomic DNA G+C content of strain $\mathrm{Ki}-1^{\mathrm{T}}$ was $45.3 \mathrm{~mol} \%$, as determined by the HPLC method described by Tamaoka \& Komagata (1984). The morphological, biochemical and physiological properties that differentiate strain Ki8- $1^{\mathrm{T}}$ from $M$. hungatei are summarized in Table 1.

The 16S rRNA genes of strain Ki8- $1^{\mathrm{T}}$ and $M$. hungatei NBRC $100397^{\mathrm{T}}$ were amplified by PCR with primers A10F $\left(5^{\prime}\right.$-TCYGGTTGATCCYGCCRG- $\left.{ }^{\prime}\right)$ and A1400R (5'ACGGGCGGTGTGTGCAAG-3'), and almost-complete $16 \mathrm{~S}$ rRNA gene sequences for the two strains (1260 and 1259 bases, respectively) were determined. After alignment using the ARB software (Ludwig et al., 2004), phylogenetic

Table 1. Morphological, biochemical and physiological properties that differentiate strain $\mathrm{Ki} 8-1^{\top}$ from $M$. hungatei NBRC $100397^{\top}$

Data from this study. Both strains are weakly motile, Gram-stainnegative, curved rods with polar or tufted flagella.

\begin{tabular}{|lcc|}
\hline Characteristic & Ki8-1 $^{\text {T }}$ & M. hungatei \\
\hline Cell width $(\mu \mathrm{m})$ & $0.5-0.6$ & $0.4-0.5$ \\
Cell length $(\mu \mathrm{m})$ & $11-25$ & $7.4-20$ \\
& $($ often $8-26)$ & (often 15 to $>100)$ \\
Temperature for growth $\left({ }^{\circ} \mathrm{C}\right)$ & & \\
$\quad$ Optimum & 30 & 45 \\
$\quad$ Range & $15-37$ & $20-50$ \\
pH for growth & & \\
$\quad$ Optimum & 7.5 & $7.0-9.0$ \\
$\quad$ Range & $6.0-9.5$ & $6.5-10.0$ \\
DNA G+C content $(\mathrm{mol} \%)$ & $45.3(\mathrm{HPLC})$ & $45-49.5\left(T_{\mathrm{m}}\right)^{*}$ \\
Source & Soil & Sewage sludge \\
& & \\
\hline
\end{tabular}

${ }^{\star}$ Data from Ferry et al. (1974) and Patel et al. (1976). 
trees were reconstructed by the neighbour-joining method with the program CLUSTAL_X (Saitou \& Nei, 1987; Thompson et al., 1997) and the maximum-likelihood method with the MORPHY software package (Adachi \& Hasegawa, 1995). The topologies of the trees generated by these two methods were almost identical, and strain Ki8- $1^{\mathrm{T}}$ was located near $M$. hungatei NBRC $100397^{\mathrm{T}}$, which represents a single family, genus and species in the order Methanomicrobiales (Fig. 2). The 16S rRNA gene sequence of strain $\mathrm{Ki} 8-1^{\mathrm{T}}$ showed $95.1 \%$ similarity to that of $M$. hungatei NBRC $100397^{\mathrm{T}}$. Phylogenetically, strain Ki8-1 ${ }^{\mathrm{T}}$ formed a distinct subline branching with $M$. hungatei NBRC $100397^{\mathrm{T}}$ at the periphery of the 16S rRNA gene sequence lineage that embraced related genera.

The sequence of the mcrA gene, encoding the alpha-subunit of methyl-coenzyme $\mathrm{M}$ reductase, was also determined for phylogenetic comparison between strain Ki8- $1^{\mathrm{T}}$ and $M$. hungatei. This gene was partially amplified from strain Ki8- $1^{\mathrm{T}}$ by PCR with primers MR1 and ME2 (Hales et al., 1996; Simankova et al., 2003). The amplified morA genes were cloned into pT7Blue T-vector (Takara Bio), and the sequence (1109 bases; GenBank/EMBL/DDBJ accession number for strain Ki8- $1^{\mathrm{T}}$, AB517988) was determined by using M13 primers. The McrA amino acid sequence deduced from the $m c r A$ gene sequence of strain Ki8- $1^{\mathrm{T}}$ showed $91.1 \%$ similarity to that of $M$. hungatei JF- $1^{\mathrm{T}}$ (GenBank/EMBL/DDBJ accession number CP000254).

Cells of strain Ki8-1 ${ }^{\mathrm{T}}$ were curved or wavy rods, strictly anaerobic and Gram-stain-negative, possessed a single polar flagellum or tufted flagella, used $\mathrm{H}_{2} / \mathrm{CO}_{2}$ or formate and required acetate. These properties are similar to those described for M. hungatei (Boone et al., 2001; Ferry et al., 1974), although $M$. hungatei also forms wavy filaments several hundred micrometres long. However, the 16S rRNA gene sequence of strain Ki8- $1^{\mathrm{T}}$ showed only $95 \%$ similarity to that of M. hungatei NBRC $100397^{\mathrm{T}}$, and the branching of strain Ki8- $1^{\mathrm{T}}$ and M. hungatei NBRC $100397^{\mathrm{T}}$ was supported by bootstrap probability scores of $100 \%$ in the two phylogenetic analysis methods employed. In addition, the temperature for growth of strain Ki8- $1^{\mathrm{T}}$ was different from that of $M$. hungatei. The optimum temperature and range for growth of strain Ki8- $1^{\mathrm{T}}$ were 30 and $15-37{ }^{\circ} \mathrm{C}$, respectively, lower than those of $M$. hungatei.

On the basis of its phylogenetic position, morphology, and biochemical and physiological properties, strain Ki8- $1^{\mathrm{T}}$ is a member of the genus Methanospirillum separate from $M$. hungatei. We therefore suggest that strain Ki8- $1^{\mathrm{T}}$ represents a novel species of the genus Methanospirillum, for which the name Methanospirillum lacunae sp. nov. is proposed.

The optimum temperature and $\mathrm{pH}$ for growth of $M$. hungatei were originally given as $37^{\circ} \mathrm{C}$ and $\mathrm{pH} 7.0$ (Boone et al., 2001; Ferry et al., 1974), whereas values of $37-45^{\circ} \mathrm{C}$ and $\mathrm{pH}$ 7.0-9.0 were found in the present study. Differences in these properties had already been suggested by Patel et al. (1976), and our study supported this conclusion. Therefore, emended descriptions of the genus Methanospirillum and of $M$. hungatei are also proposed here based on data given by Patel et al. (1976) and presented here.

\section{Emended description of the genus Methanospirillum Ferry et al. 1974}

Strictly anaerobic, mesophilic, neutrophilic or mildly alkaliphilic. Cells are Gram-stain-negative, non-sporulating and motile by polar, tufted flagella. Cells form curved or wavy rods with blunt ends. Produce methane from $\mathrm{H}_{2}$ or formate. The $\mathrm{G}+\mathrm{C}$ content of the genomic DNA is 45$49.5 \mathrm{~mol} \%$. Represent a distinct phylogenetic lineage in the family Methanospirillaceae based on 16S rRNA gene sequence analysis. The type species is Methanospirillum hungatei.

\section{Emended description of Methanospirillum hungatei Ferry et al. 1974}

The following properties are additional to those given for the genus. Cells are $0.4-0.5 \times 7.4-10 \mu \mathrm{m}$ in size, and often

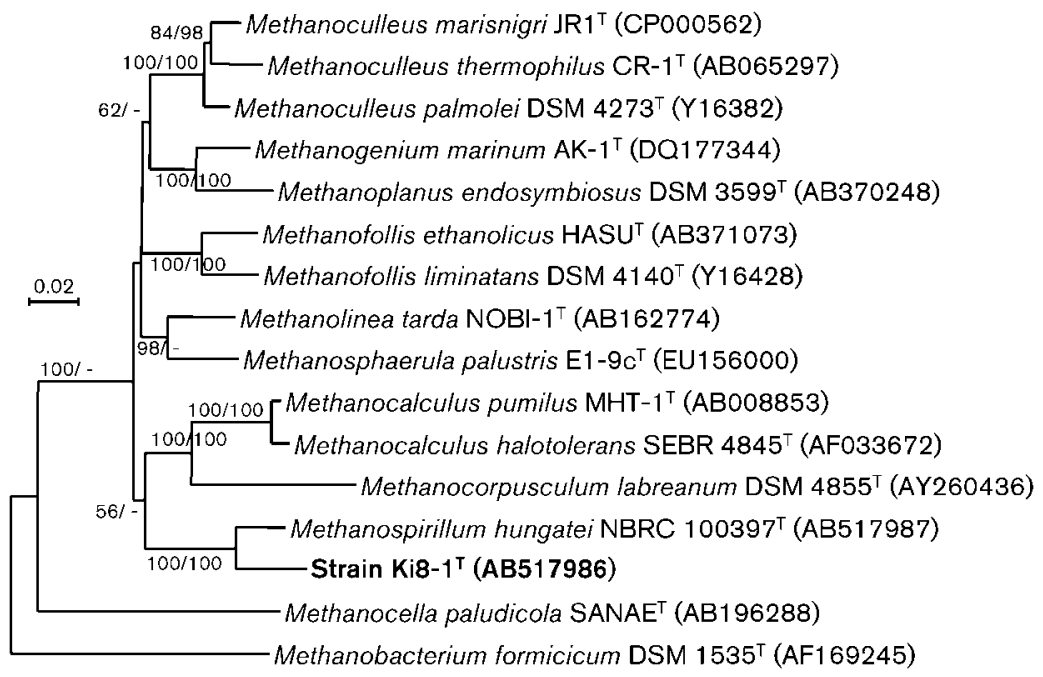

Fig. 2. Phylogenetic tree showing the position of strain $\mathrm{Ki} 8-1^{\top}$ among related species based on $16 \mathrm{~S}$ rRNA gene sequences. The tree was based on an alignment of $1255 \mathrm{bp}$ of $16 \mathrm{~S}$ rRNA gene sequences and was reconstructed by using the neighbour-joining method. Numbers at nodes are bootstrap percentages derived from 1000 replications (neighbourjoining method/maximum-likelihood method). Bar, 0.02 substitutions per nucleotide position. 
form wavy filaments from $15 \mu \mathrm{m}$ to several hundred micrometres long. Growth occurs at $20-50{ }^{\circ} \mathrm{C}$, with optimum growth at $37-45{ }^{\circ} \mathrm{C}$. The $\mathrm{pH}$ range for growth is 6.5-10.0, with optimum growth at $\mathrm{pH} 7.0-9.0$. Growth occurs below $1 \% \mathrm{NaCl}(\mathrm{w} / \mathrm{v})$, with optimum growth in basal medium without the addition of $\mathrm{NaCl}$. Methane is produced from $\mathrm{H}_{2}$ and formate, but not from acetate, pyruvate, methanol, ethanol, 1-propanol, 2-propanol, 1butanol, 2-butanol or trimethylamine. Acetate or yeast extract is required for growth. The $\mathrm{G}+\mathrm{C}$ content of the genomic DNA of the type strain is $45-49.5 \mathrm{~mol} \%$.

The type strain, JF- $1^{\mathrm{T}}\left(=\mathrm{NBRC} 100397^{\mathrm{T}}\right)$, was isolated from sewage sludge.

\section{Description of Methanospirillum lacunae sp. nov.}

Methanospirillum lacunae (la.cu'nae. L. fem. n. lacuna pond; L. fem. gen. n. lacunae of a pond).

The following properties are additional to those given for the genus. Cells are $0.5-0.6 \times 11-25 \mu \mathrm{m}$ in size, and often from 8 to $26 \mu \mathrm{m}$ in length. Growth occurs at $15-37{ }^{\circ} \mathrm{C}$, with optimum growth at $30{ }^{\circ} \mathrm{C}$. The $\mathrm{pH}$ range for growth is 6.0-9.5, with optimum growth at $\mathrm{pH}$ 7.5. Growth occurs below $1 \% \mathrm{NaCl}(\mathrm{w} / \mathrm{v})$, with optimum growth in basal medium without the addition of $\mathrm{NaCl}$. Methane is produced from $\mathrm{H}_{2}$ and formate, but not from acetate, pyruvate, methanol, ethanol, 1-propanol, 2-propanol, 1butanol, 2-butanol or trimethylamine. Acetate or yeast extract is required for growth. The $\mathrm{G}+\mathrm{C}$ content of the genomic DNA of the type strain is $45.3 \mathrm{~mol} \%$.

The type strain, Ki8- $1^{\mathrm{T}}\left(=\mathrm{NBRC} 104920^{\mathrm{T}}=\mathrm{JCM} 16384^{\mathrm{T}}\right.$ $=$ DSM $22751^{\mathrm{T}}$ ), was isolated from puddly soil in Kisarazu, Chiba, Japan.

\section{References}

Adachi, J. \& Hasegawa, M. (1995). Improved dating of the human chimpanzee separation in the mitochondrial-DNA tree: heterogeneity among amino-acid sites. J Mol Evol 40, 622-628.

Boone, D. R., Whitman, W. B. \& Koga, Y. (2001). Family III. Methanospirillaceae fam. nov. In Bergey's Manual of Systematic Bacteriology, 2nd edn, vol. 1, pp. 264-267. Edited by D. R. Boone \& R. W. Castenholz. New York: Springer.

Bräuer, S. L., Cadillo-Quiroz, H., Yadhiro, E., Yavitt, J. B. \& Zinder, S. H. (2006). Isolation of a novel acidiphilic methanogen from an acidic peat bog. Nature 442, 192-194.

Ferry, J. G., Smith, P. H. \& Wolfe, R. S. (1974). Methanospirillum, a new genus of methanogenic bacteria, and characterization of
Methanospirillum hungatii sp. nov. Int J Syst Bacteriol 24, 465469.

Garrity, G. M. \& Holt, J. G. (2001). Phylum AII. Euryarchaeota phy. nov. In Bergey's Manual of Systematic Bacteriology, 2nd edn, vol. 1, pp. 211-213. Edited by D. R. Boone \& R. W. Castenholz. New York: Springer.

Hales, B. A., Edwards, C., Ritchie, D. A., Hall, G., Pickup, R. W. \& Saunders, J. R. (1996). Isolation and identification of methanogenspecific DNA from blanket bog peat by PCR amplification and sequence analysis. Appl Environ Microbiol 62, 668-675.

Jones, W. J., Nagle, D. P., Jr \& Whitman, W. B. (1987). Methanogens and the diversity of archaebacteria. Microbiol Rev 51, 135-177.

Joye, S. B., Samarkin, V. A., Orcutt, B. N., MacDonald, I. R., Hinrichs, K.-U., Elvert, M., Teske, A. P., Lloyd, K. G., Lever, M. A. \& other authors (2009). Metabolic variability in seafloor brines revealed by carbon and sulphur dynamics. Nature Geosci 2, 349-354.

Liu, Y. \& Whitman, W. B. (2008). Metabolic, phylogenetic, and ecological diversity of the methanogenic archaea. Ann N Y Acad Sci 1125, 171-189.

Ludwig, W., Strunk, O., Westram, R., Richter, L., Meier, H., Yadhukumar, Buchner, A., Lai, T., Steppi, S. \& other authors (2004). ARB: a software environment for sequence data. Nucleic Acids Res 32, 1363-1371.

Narihiro, T., Terada, T., Ohashi, A., Wu, J.-H., Liu, W.-T., Araki, N., Kamagata, Y., Nakamura, K. \& Sekiguchi, Y. (2009). Quantitative detection of culturable methanogenic archaea abundance in anaerobic treatment systems using the sequence-specific rRNA cleavage method. ISME J 3, 522-535.

Patel, G. B., Roth, L. A., van den Berg, L. \& Clark, D. S. (1976). Characterization of a strain of Methanospirillum hungatii. Can J Microbiol 22, 1404-1410.

Saitou, N. \& Nei, M. (1987). The neighbor-joining method: a new method for reconstructing phylogenetic trees. Mol Biol Evol 4, 406425.

Simankova, M. V., Kotsyurbenko, O. R., Lueders, T., Nozhevnikova, A. N., Wagner, B., Conrad, R. \& Friedrich, M. W. (2003). Isolation and characterization of new strains of methanogens from cold terrestrial habitats. Syst Appl Microbiol 26, 312-318.

Tamaoka, J. \& Komagata, K. (1984). Determination of DNA base composition by reversed-phase high-performance liquid chromatography. FEMS Microbiol Lett 25, 125-128.

Thompson, J. D., Gibson, T. J., Plewniak, F., Jeanmougin, F. \& Higgins, D. G. (1997). The CLUSTAL_X windows interface: flexible strategies for multiple sequence alignment aided by quality analysis tools. Nucleic Acids Res 25, 4876-4882.

Touzel, J. P. \& Albagnac, G. (1983). Isolation and characterization of Methanococcus mazei strain $\mathrm{MC}_{3}$. FEMS Microbiol Lett 16, 241-245.

Wolin, E. A., Wolin, M. J. \& Wolfe, R. S. (1963). Formation of methane by bacterial extracts. J Biol Chem 238, 2882-2886.

Zengler, K., Richnow, H. H., Rosselló-Mora, R., Michaelis, W. \& Widdel, F. (1999). Methane formation from long-chain alkanes by anaerobic microorganisms. Nature 401, 266-269. 